\title{
TIPE DATA TERSTRUKTUR
}

\author{
Dwi Miftahul Janah \\ 185100022 \\ Fakultas Komputer \\ dwimiftahuljanah.student@umitra.ac.id
}

\begin{abstract}
Tipe data terstruktur adalah tipe data yang dapat digunakan untuk menampung lebih dari satu tipe data dalam variabel sehingga mudah saling berhubungan dan dapat disusun dalam satu struktur. Dalam tipe data struktur setiap perubah bisa menyimpan lebih dari sebuah nilai data. Jenis jenis tipe data terstruktur yaitu Larik (Array), Rekaman (Record), Himpunan (Set). Bagi pemula, belajar bahasa pemprograman memang sulit, namun bukan berarti itu penghalang bagi kita untuk enggan belajar. Di Fakultas Informatika yang notabene khusus mempelajari ilmu-ilmu komputer sekalipun, tidak semua mahasiswanya pandai dalam bahasa pemrograman tertentu.
\end{abstract}

Kata Kunci : Tipe Data Terstruktur 
Contoh

Array

Parameter tipe index menentukan banyaknya komponen larik tersebut. Tipe index boleh berupa sembarang tipe ordinal kecuali longint dan subjangkauan dari longint. Contoh deklarasi data larik : - Type vek=array[1..100] of integer;

Deklarasi diatas berarti Vek adalah tipe data yang berupa larik yang komponennya bertipe integer dan banyaknya 100 buah. Deklarasi yang demikian disebut deklarasi larik dimensi satu (vector). Jika tipe komponen juga berupa sebuah larik lain, akan kita peroleh larik dimensi banyak. Contoh

- Type matrik =array $[1 . .100$ ,1..50] of real;

\section{Tipe Data Record}

Digunakan untuk penyimpanan suatu kelompok data dengan tipe data yang berbeda-beda. Contoh

Record

type data $=$ record nama:string;

tanggal,bulan,tahun: integer; end;

var siswa : data; \{jika siswanya banyak digunakan array var siswa :array[1..100] of data;

Tipe Data Set Sebuah set merupakan suatu himpunan yang berisi nilai (anggota). set merupakan Tipe data yang khusus untuk Pascal. Set dalam pemrograman sangat mirip dengan himpunan dalam ilmu matematik. contoh: $\mathrm{A}=\{$ $1, \quad 2, \quad 3, \quad 4, \quad 5 \quad\}$ Sintak

set of

contoh:

type Angka $=$ set of $0 . .9$; Huruf = set of 'A'..'Z'; Hari $=($ Senin, Selasa, Rabu, Kamis,

Jum'at, Sabtu, Minggu); SetHuruf $=$ set of Huruf; SetHari $=$ set of Hari; const Genap: Angka $=[0,2,4$, 6 , $8]$; Vokal: Huruf $=[$ 'A', 'E', 'I', 'O', 'U', 'Y']; Kita tidak bisa menulis atau membaca isi dari set, tetapi kita bisa melakukan operasi yang lain dengan data yang ada pada set (mis. relasional). Contoh:

Program contoh_set; type hari = (ahad, sen, sel, rab, kam,jum, $\mathrm{Sab})$; var semua_hari : set of hari; hari_kerja : set of sen .. jum; hari_ini : hari; begin

hari_ini:=sen;

if hari_ini in hari_kerja then writeln(' HARI KERJA') else writeln('HARI LIBUR'); end.

Salah satu manfaat dari penggunaan tipe data set adalah untuk mengecek apakah suatu nilai muncul dalam suatu range tertentu. Misalnya, untuk mementukan apakah suatu karakter berupa lower case letter (huruf kecil), mis. Ch adalah tipe Char, kita bisa 
menulis

if $(\mathrm{Ch}>=$ 'a') and (Ch $<=$ 'z') then

Writeln( Ch,' merupakan huruf kecil.');

atau, dengan notasi set, kita bisa menulis , if $\mathrm{Ch}$ in ['a'..'z'] then Writeln( Ch,' merupakan huruf kecil.');

\section{Tipe Data File}

\section{Procedure dan Function Standard Untuk Semua Tipe}

Assign(f:file;name:string) : digunakan untuk menghubungkan nama dari external file ke suatu variabel file.

Rewrite (f[:file; recsize:word]): digunakan untuk membuka file yang baru atau yang belum pernah ada di disk.

Reset (f[:file; recsize:word]) : digunakan untuk membuka file yang sudah ada.

Close (f:file) : : digunakan untuk menutup file yang telah dibuka dengan procedure standard Rewrite, Reset, atau Append (procedure khusus untuk membuka file teks).

Erase (f:file) : digunakan untuk menghapus suatu external file. Dalam penggunaanya harus didahului dengan procedure standard Close.

Rename

(f:file;newname:string):

digunakan untuk mengganti nama suatu external file.
GetDir (d:byte; var s:string) : digunakan untuk mengetahui direktori yang aktif pada suatu drive ChDir(s:string) :digunakan untuk mengubah posisi dari direktori.

MkDir(s:string) :digunakan untuk membuat suatu direktori. RmDir(s:string) :digunakan untuk menghapus suatu direktori.

Eof(f:file):boolean: fungsi ini akan menghasilkan status apakah file sudah berada di posisi akhir dari file atau tidak.

\section{File Teks}

File tekas merupakan file yang berisi karakter yang dibentuk dalam baris-baris dan masingmasing baris dengan end-ofline marker berupa karakter carriage return dan karakter line feed (CR/LF). Sedangkan akhir dari file ditunjukkan dengan karakter Ctrl-Z.

Panjang dari tiap-tiap baris dari file teks dapat berbeda-beda, sehingga posisi dari suatu baris tertentu dari file teks tidak dapat dihutung dan akibatnya file tekas hanya dapat diakses secara urut.

File teks sebenarnya merupakan file dengan tipe Char, tetapi mempunyai perbedaan, yaitu nilai yang bukan tipe Char dapat direkam dan dibaca oleh file teks. Nilai yang bukan tipe Char ini akan secara otomatis dirubah ke atau dari tipe Char. 


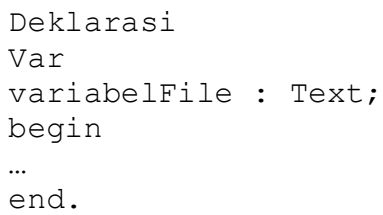

\section{Prosedur dan Fungsi Standard File Teks}

Append(var f:text); digunakan untuk membuka file yang telah ada untuk keperluan menambah data ke dalam file.

Write([var f:text; ] v1 $[\mathrm{v} 2, \ldots, \mathrm{vn}])$ : digunakan untuk merekam data ke dalam file.

Writeln([var f:text; ] v1 $[\mathrm{v} 2, \ldots, \mathrm{vn}]) \quad$ : digunakan untuk merekam data ke dalam file dan memberikan end-of-line marker.

Flush(var f:text)

digunakan untuk segera merekam data yang ada di dalam buffer ke dalam file teks.

Read([var f:text; ] v1 $[\mathrm{v} 2, \ldots, \mathrm{vn}])$ : digunakan untuk membaca satu atau lebih nilai dari file ke dalam satu variabel atau lebih.

Readln([var f:text;] v1 $[\mathrm{v} 2, \ldots, \mathrm{vn}])$ : kegunaannya sana dengan procedure Read, tetapi procedure ini akan menggeser pembacaan ke awal baris beikutnya dalam file.

Eoln[(var f:text)]:boolean

digunakan untuk mengetahui apakah posisi dari file berada di end-of-line marker atau tidak.

SeekEof[(var f:text)]:boolean kegunaannya sama dengan Eof, yaitu menghasilkan status akhir dari file.

SeekEoln[(var

f:text)]:boolean : kegunaannya sama dengan Eoln, yaitu menghasilkan status akhir dari baris.
C. ID SECURITY

QWTD4452377-ASP-5244107

D. KESIMPULAN

Dari materi di atas dapat di simpulkan Jenis dalam tipe data terstruktur yaitu Larik/array, Record, Set, File. Dalam mempelajari bahasa pemprograma diperlukan ketelitian, kesabaran dan keuletan, karena bahasa pemprograman sangat sensitive, maksudnya pada saat menuliskan sintaks suatu program tertentu, kita harus memperhatikan penulisan seintaksnya, karena walaupun kesalahan titik saja, maka program tidak bisa dijalankan (error).

\section{E. DISKUSI}

Febi : apakah artikel ini sangat membantu ?

Saya : iyaa, karena artikel ini cukup lengkap tentang artikel tipe data terstruktur.

Saya : apakah setelah membaca anda mengerti tentang artikkel ini ?

Febi : iyaa, setelah saya membaca artikel ini saya paham tentang tipe data tersrtuktur. 


\section{F. REFERENCE}

[1] O. M. Febriani and A. S. Putra, "Sistem Informasi Monitoring Inventori Barang Pada Balai Riset Standardisasi Industri Bandar Lampung," J. Inform., vol. 13, no. 1, pp. 90-98, 2014.

[2] A. S. Putra, "Paperplain: Execution Fundamental Create Application With Borland Delphi 7.0 University Of Mitra Indonesia," 2018.

[3] A. S. Putra, "2018 Artikel Struktur Data, Audit Dan Jaringan Komputer," 2018.

[4] A. S. Putra, "ALIAS MANAGER USED IN DATABASE DESKTOP STUDI CASE DB DEMOS."

[5] A. S. Putra, "COMPREHENSIVE SET OF PROFESSIONAL FOR DISTRIBUTE COMPUTING."

[6] A. S. Putra, "DATA ORIENTED RECOGNITION IN BORLAND DELPHI 7.0."

[7] A. S. Putra, "EMBARCADERO DELPHI XE 2 IN GPUPOWERED FIREMONKEY APPLICATION."

[8] A. S. Putra, "HAK ATAS KEKAYAAN INTELEKTUAL DALAM DUNIA TEKNOLOGY BERBASIS REVOLUSI INDUSTRI 4.0."

[9] A. S. Putra, "IMPLEMENTASI PERATURAN PERUNDANGAN UU. NO 31 TAHUN 2000 TENTANG DESAIN INDUSTRI BERBASIS INFORMATION TECHNOLOGY."
"IMPLEMENTATION OF PARADOX DBASE."

[11] A.

A. S. Putra, "IMPLEMENTATION OF TRADE SECRET CASE STUDY SAMSUNG MOBILE PHONE."

[12] A. S. Putra, "IMPLEMENTATION

PATENT FOR APPLICATION WEB BASED CASE STUDI WWW. PUBLIKLAMPUNG. COM",

A. S. Putra, "IMPLEMENTATION

SYSTEM FIRST TO INVENT IN DIGITALLY INDUSTRY."

[14] A. S. Putra, "MANUAL REPORT \& INTEGRATED DEVELOPMENT

ENVIRONMENT BORLAND DELPHI 7.0."

[15] A. S. Putra, "PATENT AS RELEVAN SUPPORT RESEARCH."

[16] A. S. Putra, "PATENT FOR RESEARCH STUDY CASE OF APPLE. Inc."

[17] A. S. Putra, "PATENT PROTECTION FOR APPLICATION INVENT."

[18] A. S. Putra, "QUICK REPORT IN PROPERTY PROGRAMMING."

[19] A. S. Putra, "REVIEW CIRCUIT LAYOUT COMPONENT

REQUIREMENT ON ASUS NOTEBOOK."

[20] A. S. Putra, "REVIEW TRADEMARK PATENT FOR INDUSTRIAL TECHNOLOGY BASED 4.0."

[21] A. S. Putra, "TOOLBAR COMPONENT PALLETTE IN 
OBJECT

ORIENTED

PROGRAMMING."

[22]

A. S. Putra, "WORKING DIRECTORY SET FOR PARADOX 7."

[23] A. S. Putra, "ZQUERY CONNECTION

IMPLEMENTED

PROGRAMMING

STUDI

CASE PT. BANK BCA Tbk."

[24] A. S. Putra, D. R. Aryanti, and I. Hartati, "Metode SAW (Simple Additive Weighting) sebagai Sistem Pendukung Keputusan Guru Berprestasi (Studi Kasus: SMK Global Surya)," in Prosiding Seminar Nasional Darmajaya, 2018, vol. 1, no. 1, pp. 85-97.

[25] A. S. Putra and O. M. Febriani, "Knowledge Management Online Application in PDAM Lampung Province," in Prosiding International conference on Information Technology and Business (ICITB), 2018, pp. 181-187.

[26] A. S. Putra, O. M. Febriani, and B. Bachry, "Implementasi Genetic Fuzzy System Untuk Mengidentifikasi Hasil Curian Kendaraan Bermotor Di Polda Lampung," SIMADA (Jurnal Sist. Inf. dan Manaj. Basis Data), vol. 1, no. 1, pp. 21-30, 2018.

[27] A. S. Putra, H. Sukri, and K. Zuhri, "Sistem Monitoring Realtime Jaringan Irigasi Desa (JIDES) Dengan Konsep Jaringan Sensor Nirkabel," IJEIS (Indonesian J. Electron. Instrum. Syst., vol. 8, no. 2, pp. 221-232.

[28] D. P. Sari, O. M. Febriani, and
A. S. Putra, "Perancangan Sistem Informasi SDM Berprestasi pada SD Global Surya," in Prosiding Seminar Nasional Darmajaya, 2018, vol. 1, no. 1, pp. 289-294. 